\title{
A comparative numerical study of premixed and non-premixed ethylene flames
}

\author{
FOKION N. EGOLFOPOULOS ${ }^{\mathrm{a}}$ and PAUL E. DIMOTAKIS ${ }^{\mathrm{b}}$
}

${ }^{a}$ Aerospace \& Mechanical Engineering Department, University of Southern California, Los Angeles, CA 90089-1453 and ${ }^{\mathrm{b}}$ Graduate Aeronautical Laboratories, California Institute of Technology, Pasadena, CA 91125.

Detailed numerical simulations of premixed and non-premixed $\mathrm{C}_{2} \mathrm{H}_{4} /$ air flames were conducted, using six available kinetic mechanisms. The results help assess differences between these mechanisms and are of interest to proposed hydrocarbon-fueled SCRAMJET concepts, in which $\mathrm{C}_{2} \mathrm{H}_{4}$ can be expected to be a major component of the thermally cracked fuel. For premixed flames, laminar flame speeds were calculated and compared with available experimental data. For non-premixed flames, ignition/extinction Z-curves were calculated for conditions of relevance to proposed SCRAMJET concepts. Results revealed a large variance in predictions of the kinetic mechanisms examined. Differences in laminar flame speeds as high as factors of 2.5 were found. For the conditions investigated, computed ignition and extinction strain rates for non-premixed flames differed by factors as high as 300 and 3, respectively. This indicates that while there are differences in hightemperature kinetics that control flame propagation and extinction, discrepancies in low-temperature kinetics that control ignition can be even more significant. Sensitivity- and species-consumption analyses indicate uncertainties in fuel kinetics and, most importantly, on the oxidation of $\mathrm{C}_{2} \mathrm{H}_{3}$ and the production of $\mathrm{CH}_{2} \mathrm{CHO}$, whose kinetics are not well known and can crucially affect production of the important $\mathrm{H}$ radicals. These findings stress the need for experimental data in premixed and nonpremixed configurations that can be used to assess these phenomena and provide the basis for a comprehensive validation.

\section{INTRODUCTION}

Ethylene $\left(\mathrm{C}_{2} \mathrm{H}_{4}\right)$ is an intermediate in the oxidative sequence of high-C hydrocarbons (e.g., Westbrook \& Dryer 1981, Bhargava \& Westmoreland 1998a,b). However, $\mathrm{C}_{2} \mathrm{H}_{4}$ kinetics are not well understood, compared to the extensively studied methane $\left(\mathrm{CH}_{4}\right)$ kinetics, for example. Furthermore, there are challenges in describing the kinetics of the destruction paths of the vinyl radical $\left(\mathrm{C}_{2} \mathrm{H}_{3}\right)$ (e.g., Marinov et al. 1995; Bhargava \& Westmoreland 
1998a,b; Marinov 1998; Wang et al. 1999). $\mathrm{C}_{2} \mathrm{H}_{3}$ is the major product of hydrogen abstraction from $\mathrm{C}_{2} \mathrm{H}_{4}$. Any uncertainties at this level of oxidation can compromise the fidelity of the overall mechanism in predicting flame properties.

The use of $\mathrm{C}_{2} \mathrm{H}_{4}$ as a practical fuel is also relevant to high-Mach-number, air-breathing propulsion concepts (e.g., Edwards 1996). The concepts pertain to flight Mach numbers, $\mathrm{M}_{\infty}$, in the range $4<\mathrm{M}_{\infty}<8$, and rely on the use of endothermic high-C hydrocarbon fuels that can be used as coolants for the fuselage and internal-flow passages. As a result, the hydrocarbon fuel will be heated to temperatures that result in thermal cracking of the parent fuel molecule. Cracking yields a fuel mix of lower-C hydrocarbons, eventually fed to the SCRAMJET combustor. Fuel temperatures as high as $800 \mathrm{~K}$ to $1050 \mathrm{~K}$ are expected (Edwards 1996). Assuming $\mathrm{C}_{12} \mathrm{H}_{26}$ to be the main constituent of kerosene-type fuels, the resulting fuel mix, under such conditions, is primarily composed of approximately equal amounts of $\mathrm{CH}_{4}$ and $\mathrm{C}_{2} \mathrm{H}_{4}$ (Egolfopoulos \& Dimotakis 1998, 2000). Thus, the description of SCRAMJET combustion becomes particularly sensitive to the details of $\mathrm{C}_{2} \mathrm{H}_{4}$ kinetics; $\mathrm{C}_{2} \mathrm{H}_{4}$ in this case is the supplied fuel and not only an intermediate.

The accurate description of the combustion response of proposed SCRAMJET concepts, is more important compared to conventional low-speed applications, with hydrodynamic time scales that are very small (high strain rates). A good description of ignition and extinction processes is essential to design. Previous numerical studies (Egolfopoulos \& Dimotakis 1998) focused on the ignition/extinction characteristics of fuel mixes expected from thermal cracking. The presence of $\mathrm{CH}_{4}$ inhibited the ignition characteristics of $\mathrm{C}_{2} \mathrm{H}_{4}$. Minor changes in $\mathrm{C}_{2} \mathrm{H}_{3}$ kinetics were found capable of modifying predicted ignition strain rates of pure $\mathrm{C}_{2} \mathrm{H}_{4}$ by factors as high as 30. A subsequent numerical study (Egolfopoulos \& Dimotakis 2000) focused on the ignition/extinction response of pure $\mathrm{C}_{2} \mathrm{H}_{4}$ and its potential ignitionenhancement through independent and simultaneous additions of such additives as NO and $\mathrm{F}_{2}$. While these promote ignition, the overall response was found to be rather sensitive to $\mathrm{C}_{2} \mathrm{H}_{4}$ oxidation kinetics.

The main goal of the present work is the comparison of predictions of a number of available mechanisms on $\mathrm{C}_{2} \mathrm{H}_{4}$ kinetics in flames. The results will help assess the state of current knowledge on the subject and the relative ability of these mechanisms to predict fundamental flame properties. 


\section{APPROACH}

Freely propagating, one-dimensional, premixed flames and opposed-jet, stagnation-flow, non-premixed flame configurations were chosen for the study, the latter to quantify the effect of fluid mechanics on ignition and extinction of non-premixed flames. Freely propagating flames were simulated to determine laminar flame speeds, $S_{\mathrm{u}}^{\mathrm{o}}$, for which reliable experimental data are available. Their prediction is a validation requirement for any mechanism. Flame propagation is very sensitive to various elementary reactions, especially those of the $\mathrm{H}_{2} / \mathrm{CO}$ subsystem. At the same time, the rate of evolution of $\mathrm{H}_{2} / \mathrm{CO}$ kinetics depends on a number of oxidation reactions of the parent fuel molecule (e.g., Westbrook \& Dryer 1981, Marinov et al. 1995, Marinov 1998), which, in many cases, can be "bottlenecks" of the overall burning process.

Laminar flame speeds were calculated using the PREMIX Sandia code (Kee et al. 1985) modified to allow for thermal radiation from $\mathrm{CO}, \mathrm{CO}_{2}$, and $\mathrm{H}_{2} \mathrm{O}$ ( $\mathrm{Law} \&$ Egolfopoulos 1992). The opposed-jet configuration was simulated by solving the conservation equations

of mass, momentum, energy, and species concentrations along the stagnation streamline (Egolfopoulos 1994, Egolfopoulos \& Campbell 1996) for steady flow. The opposed-jet code employed a two-point continuation approach to describe the entire Z-curve flame response to strain rate variation (Nishioka et al. 1996; Egolfopoulos \& Dimotakis 1998, 2000). The codes were integrated with the CHEMKIN (Kee et al. 1989) and Transport (Kee et al. 1983) subroutine libraries.

\section{CHEMICAL KINETICS MECHANISMS}

Six, recently compiled, kinetic mechanisms were chosen. All mechanisms were tested including the thermodynamic and transport data set used for each compilation. These are:

1. The Tan et al. (1994) mechanism, hereafter referred to as "TAN94", is a comprehensive mechanism developed to describe the oxidation of $\mathrm{CH}_{4}, \mathrm{C}_{2} \mathrm{H}_{4}, \mathrm{C}_{2} \mathrm{H}_{2}$, propane $\left(\mathrm{C}_{3} \mathrm{H}_{8}\right)$, and propene $\left(\mathrm{C}_{3} \mathrm{H}_{6}\right)$, individually and also as blends. The mechanism relies on 78 species and 473 reactions. 
2. The GRI 2.1 mechanism (Frenklach et al. 1995) hereafter referred to as "GRI21", was originally developed to describe a number of flame properties of methane/air mixtures, as well as methane oxidation in homogeneous systems. It contains kinetics of $\mathrm{H}_{2} / \mathrm{CO} / \mathrm{C}_{1} / \mathrm{C}_{2}$ species and has been widely used the last 4-5 years in simulations of $\mathrm{C}_{1^{-}}$and $\mathrm{C}_{2}$ hydrocarbon flames. GRI21 also contains a $\mathrm{C}_{2} \mathrm{H}_{4}$ kinetics subset and is a mechanism compiled hierarchically and as such the $\mathrm{H}_{2} / \mathrm{CO}$ and $\mathrm{CH}_{4}$ subsets can be used with confidence. The mechanism relies on 31 species and 175 reactions.

3. The Wang \& Frenklach (1997) mechanism, hereafter referred to as "WF97", was developed for the description of the formation and growth of polycyclic aromatic hydrocarbons. It maintains the basic features of GRI21, and, similarly to GRI30, it was augmented through the addition of a few species to better describe $\mathrm{C}_{2} \mathrm{H}_{4}$ and acetylene $\left(\mathrm{C}_{2} \mathrm{H}_{2}\right)$ flames. The mechanism relies on 33 species and 192 reactions.

4. The Marinov et al. (1998) mechanism, hereafter referred to as "MRN98", was developed through tests against $\mathrm{C}_{2} \mathrm{H}_{4}, \mathrm{C}_{2} \mathrm{H}_{2}$, and ethanol $\left(\mathrm{C}_{2} \mathrm{H}_{5} \mathrm{OH}\right)$ flames. The mechanism relies on 57 species and 383 reactions. An earlier version of its $\mathrm{C}_{2} \mathrm{H}_{4} / \mathrm{C}_{2} \mathrm{H}_{2}$ kinetic subsets (Marinov et al. 1995), relying on 46 species and 246 reactions was tested against experimental laminar flame speeds for $\mathrm{C}_{2} \mathrm{H}_{4}$ /air and $\mathrm{C}_{2} \mathrm{H}_{2}$ /air flames (Egolfopoulos et al. 1990).

5. The GRI 3.0 mechanism (Bowman et al. 1999), hereafter referred to as "GRI30", was recently released and retains the basic features of GRI21. It was augmented through additional species relevant to $\mathrm{C}_{2} \mathrm{H}_{4}$, the most important of which was vinyoxy $\left(\mathrm{CH}_{2} \mathrm{CHO}\right)$. A limited number of $\mathrm{C}_{3}$-related kinetic steps were also added. The mechanism relies on 35 species and 217 reactions.

6. The Wang et al. (1999) mechanism, hereafter referred to as "W99", was recently developed to describe the combustion characteristics of $\mathrm{C}_{2} \mathrm{H}_{4}, \mathrm{C}_{2} \mathrm{H}_{2}$, and $\mathrm{C}_{3} \mathrm{H}_{\mathrm{x}}$ fuels. In this model, small-species chemistry is largely based on GRI 2.1 mechanism (Frenklach et al. 1995). The reaction kinetics of acetylene and ethylene are based work reported previously (Sun et al. 1996, Wang \& Frenklach 1997, Laskin \& Wang 1999). The $\mathrm{C}_{3} \mathrm{H}_{\mathrm{x}}$ sub-model was taken from (Davis et al. 1999). The kinetic model retains a reasonable number of $\mathrm{C}_{4}$ species to ensure proper simulation under fuel-rich conditions. The mechanism relies on 52 species and 367 reactions. 


\section{RESULTS AND DISCUSSION}

\subsection{Reactant inflow conditions}

Laminar flame speeds were calculated for atmospheric $\mathrm{C}_{2} \mathrm{H}_{4} /$ air mixtures for a wide range of equivalence ratio, $\phi$, and for an unburned mixture temperature, $T_{\text {unb }}=300 \mathrm{~K}$, for which experimental data are available (Egolfopoulos et al. 1990).

Ignition/extinction Z-curves for non-premixed, opposed-jet configurations were determined by impinging an air stream on a counterflowing $\mathrm{C}_{2} \mathrm{H}_{4}$ stream, at $p=1 \mathrm{~atm}$. The simulations were conducted for a fuel-stream temperature $T_{\text {fuel }}=950 \mathrm{~K}$, and for an air-stream temperature $T_{\text {air }}=1200 \mathrm{~K}$. While the choice of $T_{\text {fuel }}$ is consistent with one used in previous studies (Egolfopoulos \& Dimotakis 1998, 2000), an air temperature of $T_{\text {air }}=1200 \mathrm{~K}$ was chosen as the minimum air temperature for which all mechanisms produce ignition. Z-curves were calculated initializing with vigorously burning flames and gradually reducing the $\mathrm{H}$ radical pool, following the two-point continuation approach described above. They were represented through the variation of the maximum mass fraction of $\mathrm{H}$ radicals, $Y_{\mathrm{Hmax}}$, with strain rate, $\sigma$. The latter was defined as minus the convective velocity gradient, on the air side, just before the main chemical-activity zone. Through sensitivity analyses (Kee et al. 1985) and integrated species-consumption path analyses (Egolfopoulos \& Dimotakis 1998, 2000), the details controlling flame propagation as well as the Z-curve ignition/extinction response were identified.

\subsection{Laminar flame speeds}

Figure 1 depicts the experimental and calculated values of $S_{\mathrm{u}}^{\mathrm{o}}$. Discrepancies in the predictions of $S_{\mathrm{u}}^{\mathrm{o}}$ are evident. For stoichiometric $(\phi=1.0)$ and rich $(\phi=1.6)$ flames, for example, $S_{\mathrm{u}}^{\mathrm{o}}$ predictions vary by as much as a factor of 1.6 and 2.5 respectively, a range considered excessive for flame propagation. Adjusting for agreement would require significant modification in the kinetics.

GRI30 produces the highest values, while MRN98 the lowest. TAN94 and W99 achieve best agreement with experimental values. The low predictions of MRN98 are not in accord with previously reported comparisons (Marinov et al. 1995). Some discrepancies pertaining to the 
$\mathrm{C}_{2} \mathrm{H}_{4}$ kinetic subset may exist between the two mechanisms (the Marinov et al. 1995 mechanism was not available to us).

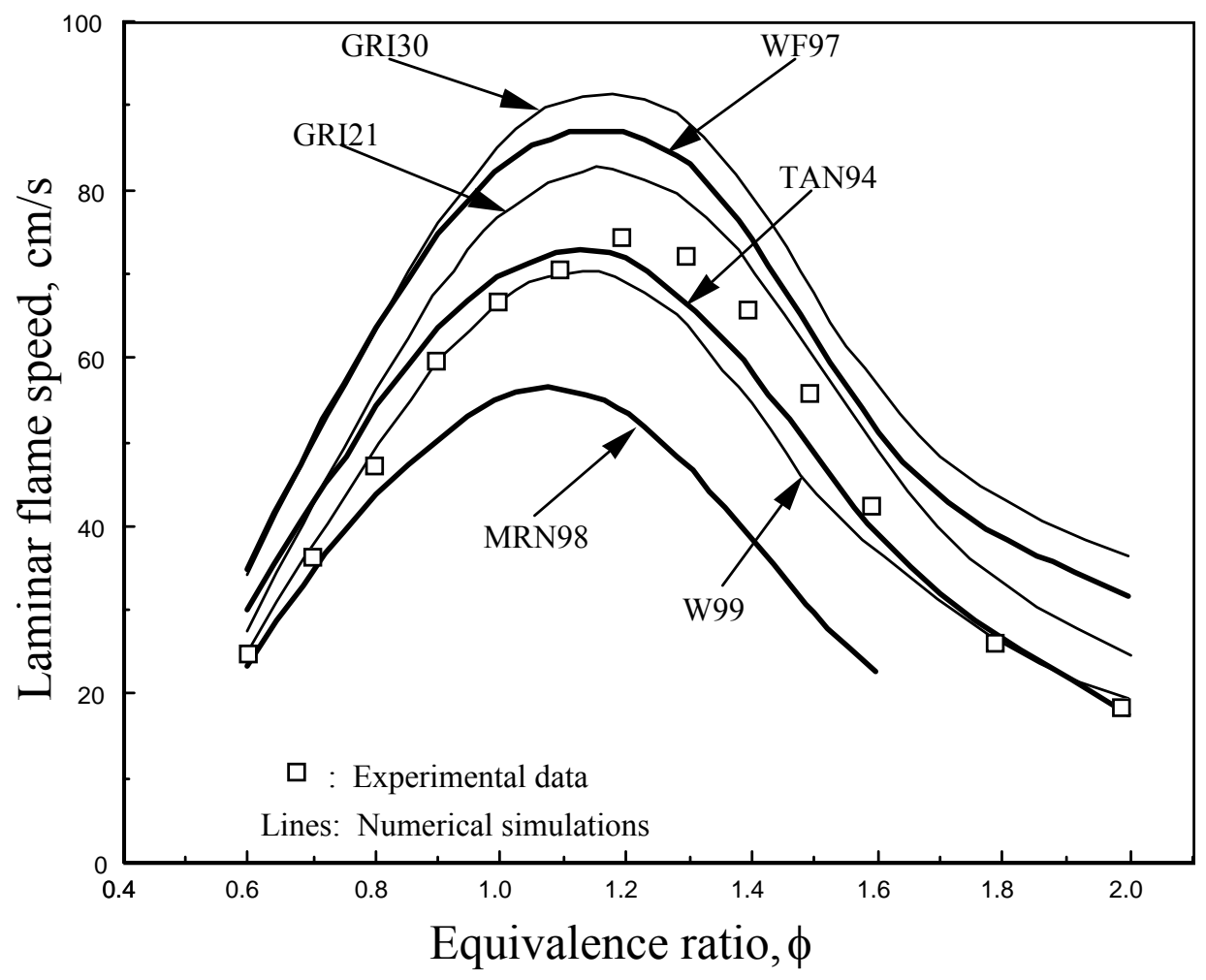

FIGURE 1. Calculated laminar flame speeds for atmospheric $\mathrm{C}_{2} \mathrm{H}_{4} /$ air flames with $T_{\text {unb }}=300 \mathrm{~K}$ and comparison with experimental data (Egolfopoulos et al. 1990).

Figures 2 and 3 depict the effect of the various mechanisms on the normalized sensitivity coefficients (SC) on the mass-burning rate of a stoichiometric $(\phi=1.0) \mathrm{C}_{2} \mathrm{H}_{4}$ /air flame. Given the large number of reactions involved, only those characterized by the greatest sensitivity are presented.

All mechanisms examined yield similar, positive $\mathrm{SC}$ 's for the $\mathrm{H}+\mathrm{O}_{2} \rightarrow \mathrm{OH}+\mathrm{O}$ and $\mathrm{CO}+\mathrm{OH} \rightarrow \mathrm{CO}_{2}+\mathrm{H}$ reactions, that are chiefly responsible for radical branching and heat release, respectively. All mechanisms also have similar, positive SC's for the H-producing $\mathrm{HCO}+\mathrm{M} \rightarrow \mathrm{CO}+\mathrm{H}+\mathrm{M}$ reaction. Noticeable $\mathrm{SC}^{\prime} \mathrm{s}$ to $\mathrm{C}_{2} \mathrm{H}_{4} \mathrm{H}$-abstraction reactions are observed for WF97, GRI30, and W99 $\left(\mathrm{C}_{2} \mathrm{H}_{4}+\mathrm{OH} \rightarrow \mathrm{C}_{2} \mathrm{H}_{3}+\mathrm{H}_{2} \mathrm{O}\right)$ and TAN94 $\left(\mathrm{C}_{2} \mathrm{H}_{4}+\mathrm{O} \rightarrow \mathrm{CH}_{2}+\mathrm{HCO}+\mathrm{H}\right)$. GRI21 and MRN98 do not exhibit significant positive SC's to $\mathrm{C}_{2} \mathrm{H}_{4}$ reactions. Interestingly, GRI30 has a noticeable positive $\mathrm{SC}$ to the vinyoxy-producing, $\mathrm{C}_{2} \mathrm{H}_{3}+\mathrm{O}_{2} \rightarrow \mathrm{CH}_{2} \mathrm{CHO}+\mathrm{O}$. 


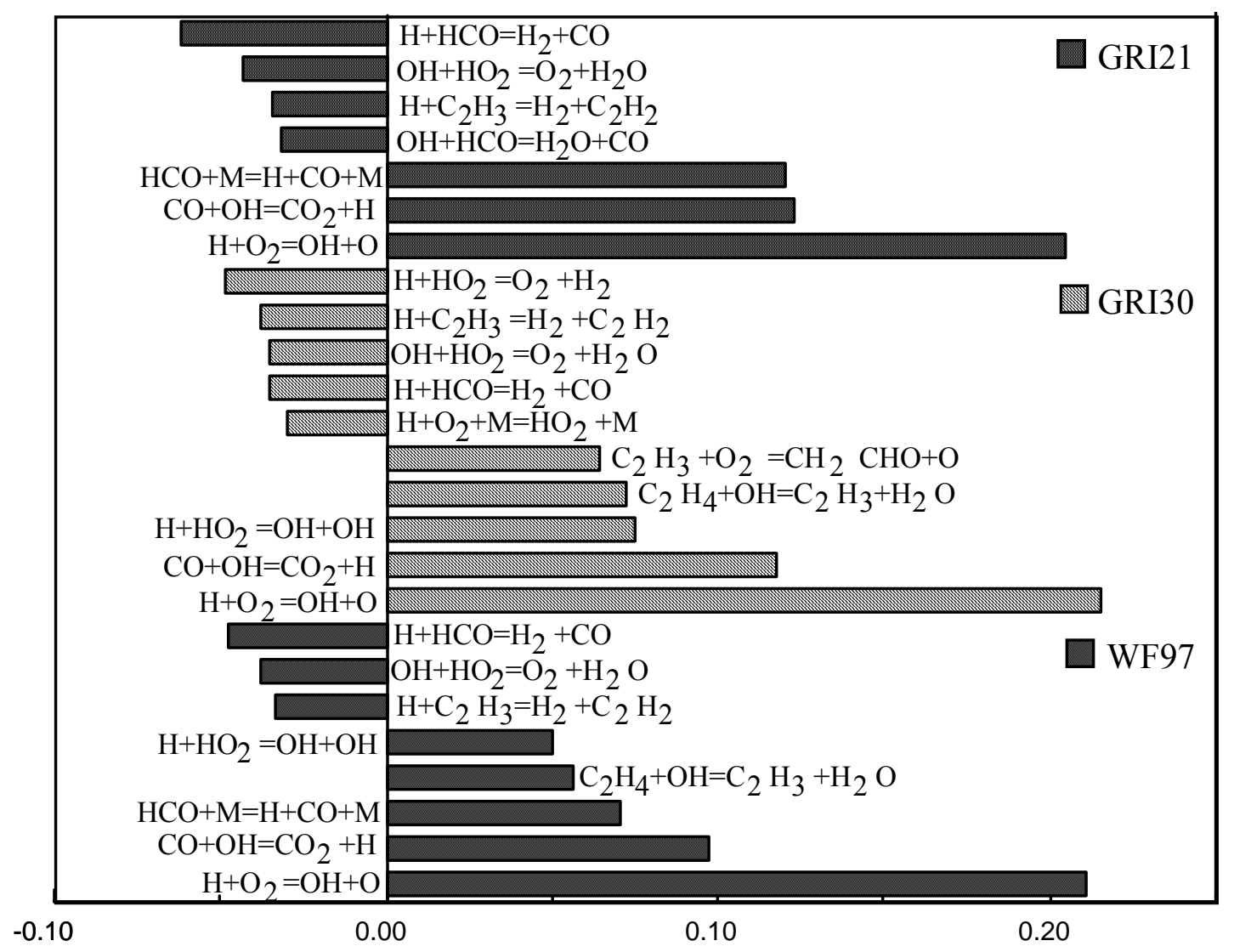

FIGURE 2. Normalized sensitivity coefficients on mass-burning rate for $\phi=1.0 \mathrm{C}_{2} \mathrm{H}_{4} /$ air flame: GRI21, GRI30, and WF97.

For all mechanisms considered, there is a noticeable negative $\mathrm{SC}$ to the H-terminating, $\mathrm{H}+\mathrm{HCO} \rightarrow \mathrm{H}_{2}+\mathrm{CO}$, as it competes for $\mathrm{HCO}$ with $\mathrm{HCO}+\mathrm{M} \rightarrow \mathrm{H}+\mathrm{CO}+\mathrm{M}$. The three-body, $\mathrm{H}+\mathrm{O}_{2}+\mathrm{M} \rightarrow \mathrm{HO}_{2}+\mathrm{M}$, has a significant terminating effect only for GRI30 and W99. GRI21, WF97, MRN98, and GRI30 exhibit negative SC's for $\mathrm{H}+\mathrm{C}_{2} \mathrm{H}_{3} \rightarrow \mathrm{H}_{2}+\mathrm{C}_{2} \mathrm{H}_{2}$. Significant negative $\mathrm{SC}^{\prime}$ 's to fuel reactions are exhibited only by TAN94. TAN94 also exhibits significant negative $\mathrm{SC}$ to $\mathrm{CH}_{3}+\mathrm{CH}_{3} \rightarrow \mathrm{C}_{2} \mathrm{H}_{5}+\mathrm{H}$.

While sensitivity analysis provides useful insights into rate-controlling mechanisms, it does not reveal the significance of kinetic steps that are not rate controlling, but may be important to the overall oxidation process. Thus, integrated-species consumption path analyses were performed for $\phi=1.0$ flames. Table 1 contains the reactions referred to in the analysis below of flame propagation. 
TABLE 1 Integrated percent species-consumption/-production analysis for one-dimensional, steady, planar, adiabatic, freely-propagating, laminar premixed flames, at $\phi=1.0$.

\begin{tabular}{|c|c|c|c|c|c|c|c|}
\hline \multicolumn{2}{|c|}{$\mathrm{C}_{2} \mathrm{H}_{4}$-consumption } & \multirow{2}{*}{$\begin{array}{r}\text { TAN94 } \\
13\end{array}$} & \multirow{2}{*}{$\begin{array}{r}\text { GRI21 } \\
30\end{array}$} & \multirow{2}{*}{$\begin{array}{r}\text { WF97 } \\
28\end{array}$} & \multirow{2}{*}{$\begin{array}{r}\text { MRN98 } \\
31\end{array}$} & \multirow{2}{*}{$\begin{array}{r}\text { GRI30 } \\
26\end{array}$} & \multirow{2}{*}{$\begin{array}{r}\text { W99 } \\
12\end{array}$} \\
\hline $\mathrm{R} 1$ & $\mathrm{C}_{2} \mathrm{H}_{4}+\mathrm{H} \rightarrow \mathrm{C}_{2} \mathrm{H}_{3}+\mathrm{H}_{2}$ & & & & & & \\
\hline $\mathrm{R} 2$ & $\mathrm{C}_{2} \mathrm{H}_{4}+\mathrm{H}+\mathrm{M} \rightarrow \mathrm{C}_{2} \mathrm{H}_{5}+\mathrm{M}$ & 16 & 8 & 10 & 9 & 7 & 6 \\
\hline R3 & $\mathrm{C}_{2} \mathrm{H}_{4}+\mathrm{O} \rightarrow \mathrm{CH}_{2} \mathrm{CHO}+\mathrm{H}$ & 0 & 0 & 0 & 9 & 13 & 0 \\
\hline R4 & $\mathrm{C}_{2} \mathrm{H}_{4}+\mathrm{O} \rightarrow \mathrm{CH}_{3}+\mathrm{HCO}$ & 22 & 29 & 35 & 26 & 24 & 30 \\
\hline R5 & $\mathrm{C}_{2} \mathrm{H}_{4}+\mathrm{O} \rightarrow \mathrm{C}_{2} \mathrm{H}_{3}+\mathrm{OH}$ & 0 & 0 & 0 & 0 & 0 & 14 \\
\hline R6 & $\mathrm{C}_{2} \mathrm{H}_{4}+\mathrm{O} \rightarrow \mathrm{C}_{2} \mathrm{H}^{(\mathrm{S})}+\mathrm{HCO}+\mathrm{H}$ & 22 & 0 & 0 & 0 & 0 & 0 \\
\hline R7 & $\mathrm{C}_{2} \mathrm{H}_{4}+\mathrm{OH} \rightarrow \mathrm{C}_{2} \mathrm{H}_{3}+\mathrm{H}_{2} \mathrm{O}$ & 26 & 34 & 27 & 24 & 31 & 34 \\
\hline \multicolumn{2}{|c|}{$\mathrm{C}_{2} \mathrm{H}_{3}$-consumption } & TAN94 & GRI21 & WF97 & MRN98 & GRI30 & W99 \\
\hline $\mathrm{R} 8$ & $\mathrm{C}_{2} \mathrm{H}_{3}+\mathrm{H} \rightarrow \mathrm{C}_{2} \mathrm{H}_{2}+\mathrm{H}_{2}$ & 5 & 13 & 16 & 29 & 15 & 12 \\
\hline R9 & $\mathrm{C}_{2} \mathrm{H}_{3}+\mathrm{O}_{2} \rightarrow \mathrm{HCO}+\mathrm{CH}_{2} \mathrm{O}$ & 21 & 58 & 16 & 5 & 20 & 12 \\
\hline $\mathrm{R} 10$ & $\mathrm{C}_{2} \mathrm{H}_{3}+\mathrm{O}_{2} \rightarrow \mathrm{C}_{2} \mathrm{H}_{2}+\mathrm{HO}_{2}$ & 0 & 0 & 2 & 24 & 3 & 2 \\
\hline R11 & $\mathrm{C}_{2} \mathrm{H}_{3}+\mathrm{O}_{2} \rightarrow \mathrm{CH}_{2} \mathrm{CHO}+\mathrm{O}$ & 0 & 0 & 38 & 15 & 36 & 21 \\
\hline $\mathrm{R} 12$ & $\mathrm{C}_{2} \mathrm{H}_{3}+\mathrm{M} \rightarrow \mathrm{C}_{2} \mathrm{H}_{2}+\mathrm{H}+\mathrm{M}$ & 52 & 22 & 20 & 9 & 19 & 33 \\
\hline $\mathrm{R} 13$ & $\mathrm{C}_{2} \mathrm{H}_{3}+\mathrm{CH}_{3}+\mathrm{M} \rightarrow \mathrm{C}_{3} \mathrm{H}_{6}+\mathrm{M}$ & 16 & 0 & 0 & 0 & 0 & 0 \\
\hline $\mathrm{CH}_{2} \mathrm{C}$ & CHO-consumption & TAN94 & GRI21 & WF97 & MRN98 & GRI30 & W99 \\
\hline $\mathrm{R} 14$ & $\mathrm{CH}_{2} \mathrm{CHO}+\mathrm{H} \rightarrow \mathrm{CH}_{3}+\mathrm{HCO}$ & 0 & 0 & 0 & 20 & 8 & 41 \\
\hline $\mathrm{R} 15$ & $\mathrm{CH}_{2} \mathrm{CHO}+\mathrm{O} \rightarrow \mathrm{H}+\mathrm{CH}_{2}+\mathrm{CO}_{2}$ & 0 & 0 & 0 & 0 & 12 & 0 \\
\hline $\mathrm{R} 16$ & $\mathrm{CH}_{2} \mathrm{CHO}+\mathrm{O} \rightarrow \mathrm{CH}_{2} \mathrm{O}+\mathrm{HCO}$ & 0 & 0 & 0 & 12 & 0 & 0 \\
\hline $\mathrm{R} 17$ & $\mathrm{CH}_{2} \mathrm{CHO}+\mathrm{OH} \rightarrow \mathrm{HCO}+\mathrm{CH}_{2} \mathrm{OH}$ & 0 & 0 & 0 & 0 & 9 & 0 \\
\hline $\mathrm{R} 18$ & $\mathrm{CH}_{2} \mathrm{CHO}+\mathrm{OH} \rightarrow \mathrm{CH}_{2} \mathrm{CO}+\mathrm{H}_{2} \mathrm{O}$ & 0 & 0 & 0 & 10 & 4 & 2 \\
\hline R19 & $\mathrm{CH}_{2} \mathrm{CHO}+\mathrm{O}_{2} \rightarrow \mathrm{CH}_{2} \mathrm{CO}+\mathrm{HO}_{2}$ & 0 & 0 & 0 & 0 & 0 & 12 \\
\hline $\mathrm{R} 20$ & $\mathrm{CH}_{2} \mathrm{CHO}+\mathrm{M} \rightarrow \mathrm{CH}_{2} \mathrm{CO}+\mathrm{H}+\mathrm{M}$ & 0 & 0 & 100 & 36 & 62 & 13 \\
\hline $\mathrm{R} 21$ & $\mathrm{CH}_{2} \mathrm{CHO}+\mathrm{M} \rightarrow \mathrm{CH}_{3}+\mathrm{CO}+\mathrm{M}$ & 0 & 0 & 0 & 9 & 0 & 27 \\
\hline H-pr & oduction & TAN94 & GRI21 & WF97 & MRN98 & GRI30 & W99 \\
\hline $\mathrm{R} 22$ & $\mathrm{H}_{2}+\mathrm{OH} \rightarrow \mathrm{H}_{2} \mathrm{O}+\mathrm{H}$ & 16 & 17 & 17 & 17 & 17 & 13 \\
\hline $\mathrm{R} 23$ & $\mathrm{H}_{2}+\mathrm{O} \rightarrow \mathrm{OH}+\mathrm{H}$ & 10 & 10 & 11 & 10 & 12 & 10 \\
\hline R24 & $\mathrm{CO}+\mathrm{OH} \rightarrow \mathrm{CO}_{2}+\mathrm{H}$ & 36 & 41 & 36 & 33 & 38 & 42 \\
\hline $\mathrm{R} 25$ & $\mathrm{HCO}+\mathrm{M} \rightarrow \mathrm{H}+\mathrm{CO}+\mathrm{M}$ & 9 & 8 & 11 & 11 & 4 & 13 \\
\hline
\end{tabular}


In the GRI21 mechanism, the fuel is consumed through reactions with $\mathrm{H}[\mathrm{R} 1(30 \%)]$, $\mathrm{O}[\mathrm{R} 4(29 \%)]$, and $\mathrm{OH}[\mathrm{R} 7(34 \%)]$; the percentage indicates contribution of each reaction to the overall consumption. A minor contribution by the three-body Reaction R2(8\%) is also noted. $\mathrm{C}_{2} \mathrm{H}_{3}$ is subsequently consumed through reactions with $\mathrm{H}$ [R8(13\%)], $\mathrm{O}_{2}$ [R9(58\%)], and by the decomposition Reaction R12(22\%). In the GRI30 mechanism, the fuel is consumed through Reactions $\mathrm{H}[\mathrm{R} 1(26 \%)$ and R2(7\%)], O [R3(13\%) and R4(24\%)], and $\mathrm{OH}[\mathrm{R} 7(31 \%)] . \mathrm{C}_{2} \mathrm{H}_{3}$ is subsequently consumed through reactions with $\mathrm{H}[\mathrm{R} 8(15 \%)]$, $\mathrm{O}_{2}[\mathrm{R} 9(20 \%), \mathrm{R} 10(3 \%)$, and $\mathrm{R} 11(36 \%)]$, and by the thermal decomposition Reaction $\mathrm{R} 12(19 \%) . \mathrm{CH}_{2} \mathrm{CHO}$ is consumed through reactions with the radicals $\mathrm{H}[\mathrm{R} 14(8 \%)]$, $\mathrm{O}[\mathrm{R} 15(12 \%)], \mathrm{OH}[\mathrm{R} 17(9 \%)$ and $\mathrm{R} 18(4 \%)]$, and through the thermal decomposition Reaction R20(62\%).

There are significant differences between GRI21 and GRI30 at the fuel level. $\mathrm{CH}_{2} \mathrm{CHO}$ is not included in GRI21, as previously noted (Egolfopoulos \& Dimotakis 1998). GRI30 indicates production of $\mathrm{CH}_{2} \mathrm{CHO}$ directly from the fuel (R3) and from $\mathrm{C}_{2} \mathrm{H}_{3}$ (R11). Subsequent reactions of $\mathrm{CH}_{2} \mathrm{CHO}$ result in enhanced H-radical production, especially through $\mathrm{R} 20$. This partially explains the higher $S_{\mathrm{u}}^{\mathrm{o}}$ values obtained in GRI30, compared to GRI21.

In the WF97 mechanism, the fuel is consumed through reactions with $\mathrm{H}[\mathrm{R} 1(28 \%)$ and $\mathrm{R} 2(10 \%)], \mathrm{O}[\mathrm{R} 4(35 \%)]$, and $\mathrm{OH}[\mathrm{R} 7(27 \%)] . \quad \mathrm{C}_{2} \mathrm{H}_{3}$ is subsequently consumed through reactions with $\mathrm{H}[\mathrm{R} 8(16 \%)], \mathrm{O}_{2}[\mathrm{R} 9(16 \%), \mathrm{R} 10(2 \%)$, and $\mathrm{R} 11(38 \%)]$, and through the thermal decomposition Reaction $\mathrm{R} 12(20 \%)$. $\mathrm{CH}_{2} \mathrm{CHO}$ is entirely consumed through the thermal decomposition, i.e., Reaction $\mathrm{R} 20(100 \%)$. $\mathrm{CH}_{2} \mathrm{CHO}$ is produced as in GRI30, yielding higher $S_{\mathrm{u}}^{\mathrm{o}}$ 's, compared to GRI21, since WF97 is an extension of GRI21, with the addition of $\mathrm{CH}_{2} \mathrm{CHO}$ kinetics.

In the W99 mechanism, the fuel is consumed through reactions with $\mathrm{H}[\mathrm{R} 1(12 \%)$ and $\mathrm{R} 2(6 \%)], \mathrm{O}[\mathrm{R} 4(30 \%)$ and $\mathrm{R} 5(14 \%)]$, and $\mathrm{OH}[\mathrm{R} 7(34 \%)] . \mathrm{C}_{2} \mathrm{H}_{3}$ is subsequently consumed through reactions with $\mathrm{H}[\mathrm{R} 8(12 \%)], \mathrm{O}_{2}[\mathrm{R} 9(12 \%), \mathrm{R} 10(2 \%)$, and $\mathrm{R} 11(21 \%)]$, and through the thermal decomposition Reaction $\mathrm{R} 12(33 \%) . \mathrm{CH}_{2} \mathrm{CHO}$ is consumed through reactions with H [R14(41\%)], OH [R18(2\%)], O2 [R19(12\%)], and through the thermal decomposition Reactions R20(13\%) and R21(27\%).

W99 was optimized on experimental values for $S_{\mathrm{u}}^{\mathrm{o}}$ (Egolfopoulos et al. 1990) and, as a result, its values for $S_{\mathrm{u}}^{\mathrm{o}}$ are closer to experiments, compared to the high GRI30 and WF97 values. While the latter two include $\mathrm{CH}_{2} \mathrm{CHO}$ chemistry, W99 has a lower $\mathrm{CH}_{2} \mathrm{CHO} \mathrm{H}-$ 
radical production rate (through R20), admitting additional consumption paths (R14 and $\mathrm{R} 21)$, responsible for less-reactive products.

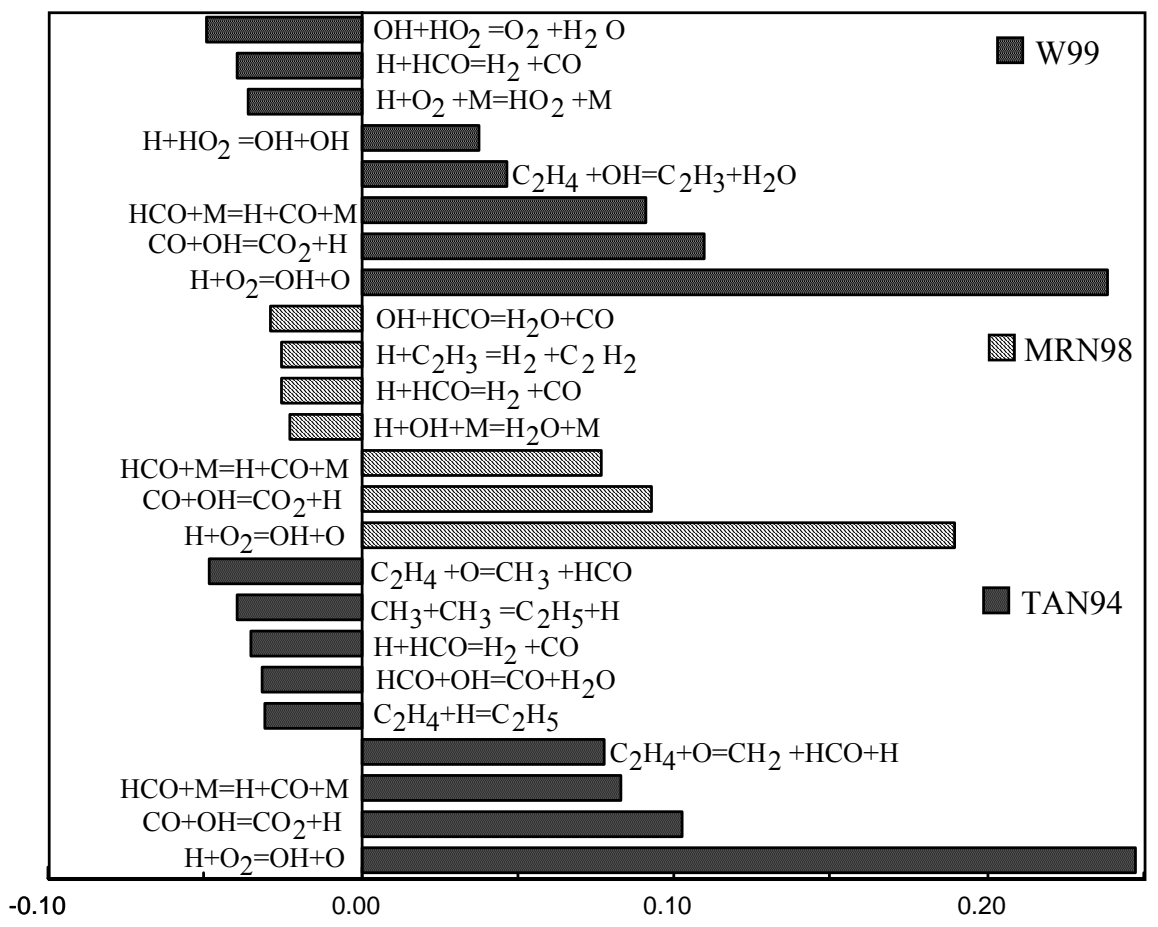

FIGURE 3. Normalized sensitivity coefficients on mass burning rate of $\phi=1.0 \mathrm{C}_{2} \mathrm{H}_{4} /$ air flame: W99, MRN98, and TAN94.

In MRN98, the fuel is consumed through reactions with $H[R 1(31 \%)$ and $R 2(9 \%)]$, $\mathrm{O}[\mathrm{R} 3(9 \%)$ and $\mathrm{R} 4(26 \%)]$, and $\mathrm{OH}[\mathrm{R} 7(24 \%)] . \quad \mathrm{C}_{2} \mathrm{H}_{3}$ is subsequently consumed through reactions with $\mathrm{H}[\mathrm{R} 8(29 \%)], \mathrm{O}_{2}[\mathrm{R} 9(5 \%), \mathrm{R} 10(24 \%)$, and $\mathrm{R} 11(15 \%)]$, and through the thermal-decomposition $\mathrm{R} 12(19 \%) . \quad \mathrm{CH}_{2} \mathrm{CHO}$ is consumed through reactions with $\mathrm{H}[\mathrm{R} 14(20 \%)], \mathrm{O}[\mathrm{R} 16(12 \%)], \mathrm{OH}[\mathrm{R} 18(10 \%)]$, and through the thermal-decomposition Reactions R20(36\%) and R21(9\%). Note that among all mechanisms, only W99 and MRN98 allow for two decomposition channels. The relative importance between these two mechanisms appears to be different. More specifically, while in W99 R21 is twice as effective in decomposing $\mathrm{CH}_{2} \mathrm{CHO}$ compared to R20, in MRN98 R21 is four times less effective compared to R20. This demonstrates the uncertainties associated with $\mathrm{CH}_{2} \mathrm{CHO}$ chemistry in the various mechanisms. MRN98 is much slower than W99, even though it allows for the most efficient decomposition of $\mathrm{CH}_{2} \mathrm{CHO}$ to $\mathrm{CH}_{2} \mathrm{CO}$ and $\mathrm{H}$, which enhances the overall oxidation process. The other kinetic subsets of MRN98 must, therefore, be substantially slower compared to W99. 
Finally, in the TAN94 mechanism, the fuel is consumed through reactions with $\mathrm{H}[\mathrm{R} 1(13 \%)$ and $\mathrm{R} 2(16 \%)], \mathrm{O}[\mathrm{R} 4(22 \%)$ and $\mathrm{R} 6(22 \%)]$ and $\mathrm{OH}[\mathrm{R} 7(26 \%)]$. Note that R7, resulting in the singlet state $\mathrm{CH}_{2}(\mathrm{~S})$, is not considered in the fuel-consumption sequence by the other mechanisms considered. $\mathrm{C}_{2} \mathrm{H}_{3}$ is subsequently consumed through reactions with $\mathrm{H}[\mathrm{R} 8(5 \%)], \mathrm{O}_{2}[\mathrm{R} 9(21 \%)]$, through the thermal-decomposition R12(52\%), and through the three-body recombination $\mathrm{R} 13(16 \%)$. The contribution of $\mathrm{R} 13$ in $\mathrm{C}_{2} \mathrm{H}_{3}$ consumption is also unique among all mechanisms.

TAN94 does not include $\mathrm{CH}_{2} \mathrm{CHO}$, similarly to GRI21. At the same time, $\mathrm{C}_{3}$ chemistry starts being important at the $\mathrm{C}_{2} \mathrm{H}_{3}$ consumption level through $\mathrm{R} 13$. This is not exhibited by the other mechanisms. Interestingly, W99 and TAN94, two significantly different mechanisms, calculate similar values of $S_{\mathrm{u}}^{\mathrm{o}}$. Of course, while failure to predict $S_{\mathrm{u}}^{\mathrm{o}}$ is a deficiency, good prediction of $S_{\mathrm{u}}^{\mathrm{o}}$ is only necessary.

Substantial differences between the mechanisms considered are apparent, not only in the contributions of the different reactions in consuming the parent fuel molecule, as well as important intermediates, but also in the steps that participate. Given the importance of $\mathrm{H}$ radicals in the overall response of the flame, the contributions of the various reactions to $\mathrm{H}$ radical production were also studied. The results are also shown in Table 1. Reactions R22, R23, R24, and R25 involving $\mathrm{H}_{2}, \mathrm{CO}$, and $\mathrm{HCO}$ are chiefly responsible for the production of the $\mathrm{H}$ radicals, with contributions that are nearly mechanisms-independent. This reveals that all mechanisms agree closely at the $\mathrm{H}_{2} / \mathrm{CO} / \mathrm{HCO}$ level; kinetics that are best understood among all species relevant to combustion.

\subsection{Ignition/extinction response of non-premixed flames}

Figure 4 compares the Z-curve response for all six mechanisms. The turning point at the largest value of $\sigma$ represents the extinction strain rate, $\sigma_{\text {ext }}$. The turning point at the lowest value represents the ignition strain rate, $\sigma_{\text {ign }}$.

Results in Fig. 4 reveal Z-curves that differ not only in the values of $\sigma_{\text {ign }}$ and $\sigma_{\text {ext }}$, but also in shape. Notably, while GRI30 is a derivative of GRI21, with $\mathrm{CH}_{2} \mathrm{CHO}$ chemistry added, the corresponding predicted Z-curves are significantly different. The two GRI mechanisms bound the predictions of the six mechanisms. Also, while MRN98 and TAN94 (marginally) 
exhibit two-stage ignition behavior, the other mechanisms do not, although they have a noticeable change in slope at larger $Y_{H \max }$ values. Since higher $Y_{\mathrm{Hmax}}$ implies higher prevailing temperatures in the reaction zone, one can expect differences between these mechanisms over a wide range of temperatures.

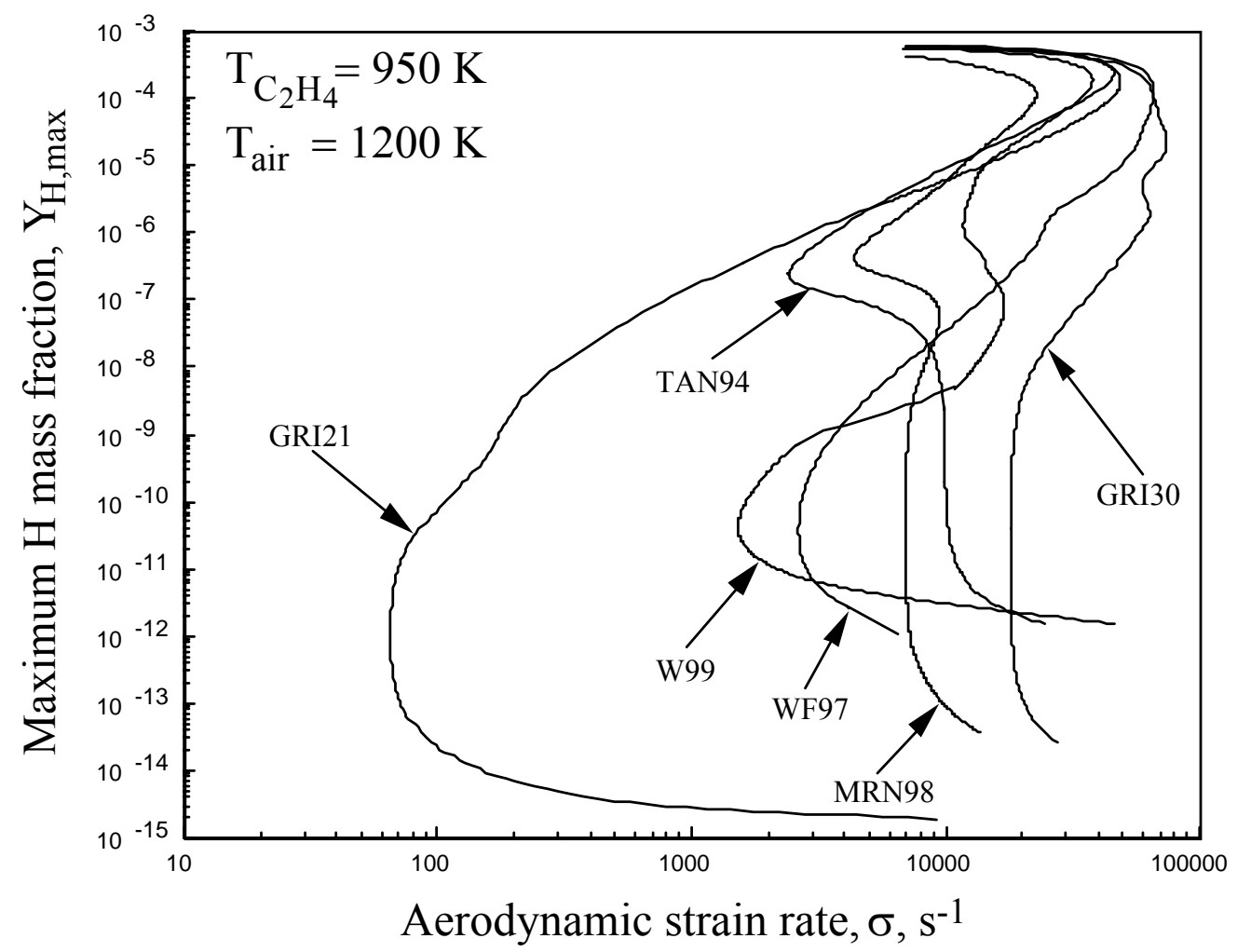

FIGURE 4. Calculated Z-curve response of non-premixed $\mathrm{C}_{2} \mathrm{H}_{4} /$ air $\quad\left(T_{\text {air }}=1200 \mathrm{~K}\right.$, $\left.T_{\text {fuel }}=950 \mathrm{~K}\right)$.

Figure 5 depicts the values of $\sigma_{\text {ign }}$ and $\sigma_{\text {ext }}$ calculated by all mechanisms, scaled by GRI 21 values. Figure $5 \mathrm{a}$ depicts $\sigma_{\text {ign }}$ results. They differ by factors as high as 300 . Figure $5 \mathrm{~b}$ depicts results for $\sigma_{\mathrm{ext}}$, as well as for $S_{\mathrm{u}}^{\mathrm{o}}$, for both stoichiometric and rich flames. $S_{\mathrm{u}}^{\mathrm{o}}$ values were included because flame propagation and extinction are high-temperature phenomena controlled by similar kinetics. Figure $5 \mathrm{~b}$ illustrates this point, with larger $S_{\mathrm{u}}^{\mathrm{o}}$ values corresponding to larger $\sigma_{\text {ext }}$ 's. The differences in the two quantities can be understood by the fact that convective transport and attendant flame-temperature-reduction influence extinction, effects that do not enter in one-dimensional, freely propagating flame models. 

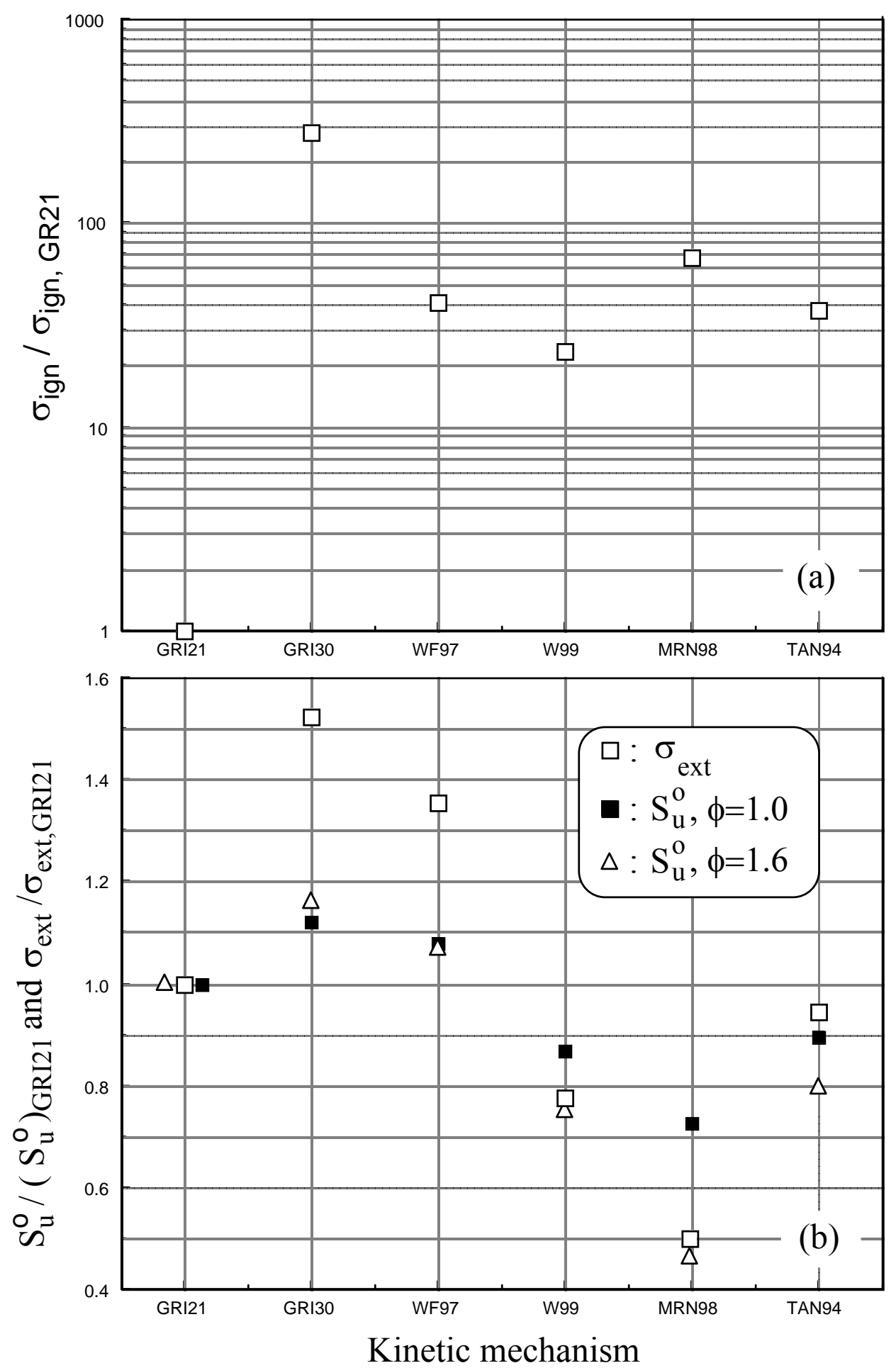

FIGURE 5. Calculated ignition and extinction strain rates (5a) for non-premixed $\mathrm{C}_{2} \mathrm{H}_{4} /$ air for $T_{\text {air }}=1200 \mathrm{~K}$ and $T_{\text {fuel }}=950 \mathrm{~K}$, and laminar flame speeds (5b) for $\phi=1.0$ and $\phi=1.6$ $\mathrm{C}_{2} \mathrm{H}_{4} /$ air flames, scaled by the corresponding GRI21 values. 
Low-temperature kinetics were assessed at the ignition points of all Z-curves (Fig. 4). For the MRN98 and TAN94 Z-curves, that exhibit two-stage ignition behavior, the lowerignition point was taken at $Y_{\mathrm{Hmax}}$ values in the range of $10^{-11}$ to $10^{-10}$. In all cases, integrated species-consumption analysis was conducted. The contributions of the most important reactions are listed in Table 2. In this regime, the fuel is consumed in GRI21 through reactions with $\mathrm{O}[\mathrm{R} 4(7 \%)], \quad \mathrm{OH}[\mathrm{R} 7(10 \%)], \quad \mathrm{HO}_{2}[\mathrm{R} 27(12 \%)]$, and the thermaldecomposition $\mathrm{R} 26(59 \%) . \mathrm{C}_{2} \mathrm{H}_{3}$ is entirely decomposed through $\mathrm{R} 9(100 \%)$. $\mathrm{H}$ radicals that are important for ignition are produced through the thermal-decomposition reactions, R25(15\%), R31(74\%), and R34(2\%).

In GRI30, the fuel is consumed through reactions with $\mathrm{H}[\mathrm{R} 2(13 \%)], \mathrm{O}[\mathrm{R} 3(12 \%)$ and $\mathrm{R} 4(22 \%)], \mathrm{OH}[\mathrm{R} 27(20 \%)], \mathrm{CH}_{3}[\mathrm{R} 29(7 \%)]$, and the thermal-decomposition $\mathrm{R} 26(20 \%)$. $\mathrm{C}_{2} \mathrm{H}_{3}$ is subsequently consumed through reactions with $\mathrm{O}_{2}[\mathrm{R} 9(40 \%)$ and $\mathrm{R} 11(56 \%)] . \mathrm{CH}_{3}$, produced in significant amounts by $\mathrm{R} 4$, is consumed through reaction with $\mathrm{C}_{2} \mathrm{H}_{4}$ [R29(89\%)]. Thus, $\mathrm{C}_{2} \mathrm{H}_{3}$ is the main product of fuel consumption.

$\mathrm{CH}_{2} \mathrm{CHO}$ is consumed through reactions with $\mathrm{O}_{2}[\mathrm{R} 30(6 \%)]$ and the thermal-decomposition R20(87\%). H radicals are produced through R3(30\%), R20(65\%), R25(5\%), and R34(1\%). Apparently, the contribution of the thermal-decomposition reactions to $\mathrm{H}$ production is reduced compared to the GRI21. Comparing GRI21 and GRI30, it is apparent that $\mathrm{CH}_{2} \mathrm{CHO}$ chemistry in GRI30 results in more efficient H-radical production, favoring ignition.

In the WF97 mechanism, the fuel is consumed through reactions with $\mathrm{H}[\mathrm{R} 2(13 \%)]$, $\mathrm{O}$ [R4(39\%)], $\mathrm{OH}[\mathrm{R} 7(18 \%)], \mathrm{CH}_{3}$ [R29(21\%)], and the thermal-decomposition $\mathrm{R} 26(2 \%)$. $\mathrm{C}_{2} \mathrm{H}_{3}$ is consumed by $\mathrm{O}_{2}[\mathrm{R} 9(37 \%)$ and $\mathrm{R} 11(58 \%)]$, as in GRI30. $\mathrm{CH}_{2} \mathrm{CHO}$ is entirely decomposed through $\mathrm{R} 20(100 \%)$ to $\mathrm{CH}_{2} \mathrm{CO}$ and $\mathrm{H}$; $\mathrm{R} 20$ is mostly (83\%) responsible for $\mathrm{H}$ radical production. Additional contributions to H-production are realized by $\mathrm{R} 25(14 \%)$ and R36(3\%).

In the W99 mechanism, the fuel is consumed through reactions with $\mathrm{H}[\mathrm{R} 2(4 \%)]$, $\mathrm{O}[\mathrm{R} 4(30 \%)$ and $\mathrm{R} 5(9 \%)], \mathrm{OH}[\mathrm{R} 7(27 \%)], \mathrm{CH}_{3}[\mathrm{R} 29(21 \%)]$, and to a minor extent by the thermal-decomposition $\mathrm{R} 26(1 \%) . \mathrm{C}_{2} \mathrm{H}_{3}$ is consumed by $\mathrm{O}_{2}[\mathrm{R} 9(36 \%)$ and $\mathrm{R} 11(60 \%)]$, as in WF97 and GRI30. $\mathrm{CH}_{2} \mathrm{CHO}$ is consumed through reactions with $\mathrm{O}_{2}[\mathrm{R} 19(66 \%)$ and $\mathrm{R} 30(9 \%)$ ], and the thermal-decomposition R20(6\%) and R21(19\%). H radicals are produced through the thermal-decomposition reactions, R20(18\%), R25(43\%), and R34(12\%), as well 
as $\mathrm{R} 33(20 \%) . \quad \mathrm{CH}_{2} \mathrm{CHO}$ is of lower importance in direct H-radical production, with lower $\sigma_{\text {ign }}$ compared to both WF97 and GRI30.

TABLE 2 Integrated percent species-consumption/-production analysis, at lower-ignition point, of strained laminar $\mathrm{C}_{2} \mathrm{H}_{4} /$ air non-premixed flames.

\begin{tabular}{|c|c|c|c|c|c|c|c|}
\hline \multicolumn{2}{|c|}{$\mathrm{C}_{2} \mathrm{H}_{4}$-consumption } & \multirow{2}{*}{$\begin{array}{r}\text { TAN94 } \\
7\end{array}$} & \multirow{2}{*}{$\begin{array}{r}\text { GRI21 } \\
0\end{array}$} & \multirow{2}{*}{$\begin{array}{r}\text { WF97 } \\
13\end{array}$} & \multirow{2}{*}{$\begin{array}{r}\text { MRN98 } \\
11\end{array}$} & \multirow{2}{*}{$\begin{array}{r}\text { GRI30 } \\
13\end{array}$} & \multirow{2}{*}{$\begin{array}{r}\text { W99 } \\
4\end{array}$} \\
\hline $\mathrm{R} 2$ & $\mathrm{C}_{2} \mathrm{H}_{4}+\mathrm{H}+\mathrm{M} \rightarrow \mathrm{C}_{2} \mathrm{H}_{5}+\mathrm{M}$ & & & & & & \\
\hline R3 & $\mathrm{C}_{2} \mathrm{H}_{4}+\mathrm{O} \rightarrow \mathrm{CH}_{2} \mathrm{CHO}+\mathrm{H}$ & 0 & 0 & 0 & 8 & 12 & 0 \\
\hline R4 & $\mathrm{C}_{2} \mathrm{H}_{4}+\mathrm{O} \rightarrow \mathrm{CH}_{3}+\mathrm{HCO}$ & 13 & 7 & 39 & 24 & 22 & 30 \\
\hline R5 & $\mathrm{C}_{2} \mathrm{H}_{4}+\mathrm{O} \rightarrow \mathrm{C}_{2} \mathrm{H}_{3}+\mathrm{OH}$ & 0 & 0 & 0 & 0 & 0 & 9 \\
\hline R6 & $\mathrm{C}_{2} \mathrm{H}_{4}+\mathrm{O} \rightarrow \mathrm{C}_{2} \mathrm{H}^{(\mathrm{S})}+\mathrm{HCO}+\mathrm{H}$ & 13 & 0 & 0 & 0 & 0 & 0 \\
\hline R7 & $\mathrm{C}_{2} \mathrm{H}_{4}+\mathrm{OH} \rightarrow \mathrm{C}_{2} \mathrm{H}_{3}+\mathrm{H}_{2} \mathrm{O}$ & 37 & 10 & 18 & 18 & 20 & 27 \\
\hline $\mathrm{R} 26$ & $\mathrm{C}_{2} \mathrm{H}_{4}+\mathrm{M} \rightarrow \mathrm{H}_{2}+\mathrm{C}_{2} \mathrm{H}_{2}+\mathrm{M}$ & 1 & 59 & 2 & 11 & 20 & 1 \\
\hline R27 & $\mathrm{C}_{2} \mathrm{H}_{4}+\mathrm{HO}_{2} \rightarrow \mathrm{C}_{2} \mathrm{H}_{5}+\mathrm{O}_{2}$ & 0 & 12 & 0 & 0 & 0 & 0 \\
\hline R28 & $\mathrm{C}_{2} \mathrm{H}_{4}+\mathrm{HO}_{2} \rightarrow \mathrm{C}_{2} \mathrm{H}_{4} \mathrm{O}+\mathrm{OH}$ & 15 & 0 & 0 & 0 & 0 & 0 \\
\hline $\mathrm{R} 29$ & $\mathrm{C}_{2} \mathrm{H}_{4}+\mathrm{CH}_{3} \rightarrow \mathrm{C}_{2} \mathrm{H}_{3}+\mathrm{CH}_{4}$ & 10 & 5 & 21 & 20 & 7 & 21 \\
\hline \multicolumn{2}{|c|}{$\mathrm{C}_{2} \mathrm{H}_{3}$-consumption } & TAN94 & GRI21 & WF97 & MRN98 & GRI30 & W99 \\
\hline R9 & $\mathrm{C}_{2} \mathrm{H}_{3}+\mathrm{O}_{2} \rightarrow \mathrm{HCO}+\mathrm{CH}_{2} \mathrm{O}$ & 100 & 100 & 37 & 41 & 40 & 36 \\
\hline R11 & $\mathrm{C}_{2} \mathrm{H}_{3}+\mathrm{O}_{2} \rightarrow \mathrm{CH}_{2} \mathrm{CHO}+\mathrm{O}$ & 0 & 0 & 58 & 57 & 56 & 60 \\
\hline \multicolumn{2}{|c|}{$\mathrm{CH}_{2} \mathrm{CHO}$-consumption } & TAN94 & GRI21 & WF97 & MRN98 & GRI30 & W99 \\
\hline R19 & $\mathrm{CH}_{2} \mathrm{CHO}+\mathrm{O}_{2} \rightarrow \mathrm{CH}_{2} \mathrm{CO}+\mathrm{HO}_{2}$ & 0 & 0 & 0 & 0 & 0 & 66 \\
\hline $\mathrm{R} 30$ & $\mathrm{CH}_{2} \mathrm{CHO}+\mathrm{O}_{2} \rightarrow \mathrm{CH}_{2} \mathrm{O}+\mathrm{CO}+\mathrm{OH}$ & 0 & 0 & 0 & 28 & 6 & 9 \\
\hline R20 & $\mathrm{CH}_{2} \mathrm{CHO}+\mathrm{M} \rightarrow \mathrm{CH}_{2} \mathrm{CO}+\mathrm{H}+\mathrm{M}$ & 0 & 0 & 100 & 53 & 87 & 6 \\
\hline $\mathrm{R} 21$ & $\mathrm{CH}_{2} \mathrm{CHO}+\mathrm{M} \rightarrow \mathrm{CH}_{3}+\mathrm{CO}+\mathrm{M}$ & 0 & 0 & 0 & 19 & 0 & 19 \\
\hline \multicolumn{2}{|r|}{ H-production } & TAN94 & GRI21 & WF97 & MRN98 & GRI30 & W99 \\
\hline R3 & $\mathrm{C}_{2} \mathrm{H}_{4}+\mathrm{O} \rightarrow \mathrm{CH}_{2} \mathrm{CHO}+\mathrm{H}$ & 0 & 0 & 0 & 29 & 30 & 0 \\
\hline R6 & $\mathrm{C}_{2} \mathrm{H}_{4}+\mathrm{O} \rightarrow \mathrm{CH}_{2}^{(\mathrm{S})}+\mathrm{HCO}+\mathrm{H}$ & 43 & 0 & 0 & 0 & 0 & 0 \\
\hline $\mathrm{R} 20$ & $\mathrm{CH}_{2} \mathrm{CHO}+\mathrm{M} \rightarrow \mathrm{CH}_{2} \mathrm{CO}+\mathrm{H}+\mathrm{M}$ & 0 & 0 & 83 & 56 & 65 & 18 \\
\hline R25 & $\mathrm{HCO}+\mathrm{M} \rightarrow \mathrm{CO}+\mathrm{H}+\mathrm{M}$ & 28 & 15 & 14 & 11 & 5 & 43 \\
\hline R31 & $\mathrm{C}_{2} \mathrm{H}_{5}+\mathrm{M} \rightarrow \mathrm{H}+\mathrm{C}_{2} \mathrm{H}_{4}+\mathrm{M}$ & 0 & 74 & 0 & 0 & 0 & 0 \\
\hline $\mathrm{R} 32$ & $\mathrm{CH}_{2}+\mathrm{O}_{2} \rightarrow \mathrm{CO}_{2}+\mathrm{H}+\mathrm{H}$ & 16 & 0 & 0 & 0 & 0 & 0 \\
\hline $\mathrm{R} 33$ & $\mathrm{C}_{2} \mathrm{H}_{4}+\mathrm{CH}_{3} \rightarrow \mathrm{C}_{3} \mathrm{H}_{6}+\mathrm{H}$ & 0 & 0 & 0 & 0 & 0 & 20 \\
\hline R34 & $\mathrm{CH}_{3} \mathrm{O}+\mathrm{M} \rightarrow \mathrm{CH}_{2} \mathrm{O}+\mathrm{H}+\mathrm{M}$ & 1 & 2 & 3 & 1 & 1 & 12 \\
\hline
\end{tabular}


In MRN98, the fuel is consumed through reactions with $\mathrm{H}[\mathrm{R} 2(11 \%)], \mathrm{O}[\mathrm{R} 3(8 \%)$ and R4(24\%)], OH [R7(18\%)], $\mathrm{CH}_{3}$ [R29(20\%)], and by the thermal-decomposition R26(11\%). As in WF97, GRI30, and W99, $\mathrm{C}_{2} \mathrm{H}_{3}$ reacts with $\mathrm{O}_{2}$ [R9(41\%) and R11(57\%)] to produce $\mathrm{CH}_{2} \mathrm{O} / \mathrm{HCO}$ and $\mathrm{CH}_{2} \mathrm{CHO} . \mathrm{CH}_{2} \mathrm{CHO}$ is consumed through reaction with $\mathrm{O}_{2}$ [R30(28\%)] and through the thermal-decomposition $\mathrm{R} 20(53 \%)$ and $\mathrm{R} 21(19 \%)$. $\mathrm{H}$ radicals are produced through the thermal-decomposition R20(56\%), R25(11\%), and R34(1\%), as well as R3(29\%). MRN98 and GRI30 are similar, with $\mathrm{CH}_{2} \mathrm{CHO}$ produced directly from the fuel and $\mathrm{H}$-radicals produced via $\mathrm{CH}_{2} \mathrm{CHO}$ decomposition to $\mathrm{H}$ and $\mathrm{CH}_{2} \mathrm{CO}$.

In TAN94, the fuel is consumed through reactions with $\mathrm{H}[\mathrm{R} 2(7 \%)], \mathrm{O}[\mathrm{R} 4(13 \%)$ and $\mathrm{R} 6(13 \%)], \quad \mathrm{OH}[\mathrm{R} 7(37 \%)], \quad \mathrm{HO}_{2}[\mathrm{R} 28(15 \%)], \mathrm{CH}_{3}[\mathrm{R} 29(10 \%)], \quad$ and by the thermaldecomposition R26(1\%). Given the omission of $\mathrm{CH}_{2} \mathrm{CHO}$ chemistry, $\mathrm{C}_{2} \mathrm{H}_{3}$ is entirely consumed by $\mathrm{O}_{2}$ [R9(100\%)] to form $\mathrm{CH}_{2} \mathrm{O}$ and $\mathrm{HCO}$, with $\mathrm{C}_{2} \mathrm{H}_{4} \mathrm{O}$ readily decomposing to $\mathrm{CH}_{3}$ and $\mathrm{HCO}$. $\mathrm{H}$ radicals are produced through $\mathrm{R} 6(43 \%)$ and $\mathrm{R} 32(16 \%)$, and through the thermal-decomposition $\mathrm{R} 25(28 \%)$ and $\mathrm{R} 34(1 \%)$. TAN94 is unique compared to the other mechanisms; it omits $\mathrm{CH}_{2} \mathrm{CHO}$ and introduces $\mathrm{C}_{2} \mathrm{H}_{4} \mathrm{O}$ as a product of fuel oxidation.

Comparing the details of all mechanisms at the ignition point, significant differences can be seen at all oxidation levels. For example, the fuel consumption paths vary noticeably, which in turn affects the production rate of $\mathrm{C}_{2} \mathrm{H}_{3}$. The most profound difference between all mechanisms, however, is the kinetics of $\mathrm{CH}_{2} \mathrm{CHO}$, which are either missing, e.g., TAN94 and GRI21, or are characterized by very different steps and rates by the various mechanisms. As shown in Table 2, this has a direct consequence on $\mathrm{H}$-radical production, which varies significantly between the mechanisms considered.

In summary and as can be seen in Tables 1 and 2, dominant species and reactions responsible for H-radical production vary significantly between propagation and extinction, on the one hand, and ignition on the other. This difference is explained by the fact that propagation and extinction entail high-activation-energy kinetics of small molecules, e.g., $\mathrm{H}_{2}, \mathrm{CO}$, and $\mathrm{HCO}$, which are fast at the high temperatures that control flame propagation and extinction. In contrast, ignition entails lower-activation-energy kinetics of large molecules, compositionally close to the parent fuel, which dominate kinetically at the lower temperatures relevant to ignition. The closer agreement between predictions of propagation and extinction between mechanisms can be traced to the better understanding and agreement 
of the kinetics of the smaller species. The large variance between ignition predictions is a manifestation of the significant uncertainties in the kinetics of larger species.

\section{CONCLUDING REMARKS}

A comparative study of six available mechanisms that include $\mathrm{C}_{2} \mathrm{H}_{4}$ kinetics was conducted in flames. Laminar-flame propagation for $\mathrm{C}_{2} \mathrm{H}_{4} /$ air mixtures and ignition/extinction (Zcurves) of non-premixed, counterflowing $\mathrm{C}_{2} \mathrm{H}_{4}$ and air were simulated. Non-premixed extinction/ignition response was determined for conditions of relevance to SCRAMJET concepts involving endothermic hydrocarbons, where $\mathrm{C}_{2} \mathrm{H}_{4}$ will be an important constituent of thermally cracked fuel.

Comparisons for both premixed and non-premixed flames reveal large differences between the mechanisms in predicted laminar flame speeds, as well as in ignition/extinction strain rates. Variations as high as a factor of 2.5 for laminar flame speeds, factors of 3 for extinction, and factors in the range 100-300 for ignition strain rates were found.

Analysis of flame structure reveals significant differences between the mechanisms at the $\mathrm{C}_{2} \mathrm{H}_{3}$ oxidation level. In particular, while some mechanisms include $\mathrm{CH}_{2} \mathrm{CHO}$, others do not. $\mathrm{CH}_{2} \mathrm{CHO}$ is important in the production of $\mathrm{H}$ radicals, on which flame speed has a dominant dependence, and which increase both ignition and extinction strain rates. Unfortunately, there are large uncertainties in $\mathrm{CH}_{2} \mathrm{CHO}$ kinetics. The role of $\mathrm{C}_{3}$ chemistry is also not clear, contributing in some mechanisms, but not in all.

Comparisons with available experimental laminar flame-speed data proved useful. The dimensionality of the unknowns in the kinetic mechanisms, is very high, and will require a suite of experiments to provide additional validation data, including ignition and extinction, under variable-pressure conditions. These are required only for $\mathrm{C}_{2} \mathrm{H}_{4}$ but also for other hydrocarbons and hydrocarbon blends whose kinetics are described by the same mechanisms. At this time, limited experimental data are available for only some small hydrocarbons, mostly at one atmosphere, and do not readily facilitate validation of the relative importance of two- and three-body reactions, for example. 


\section{Acknowledgments}

This study was funded by the Air-Breathing Propulsion program, Air Force Office of Scientific Research, Grant No. F49620-98-1-0052.

\section{References}

Bhargava, A. \& Westmoreland, P.R. 1998a Measured Flame Structure and Kinetics in a Fuel-Rich Ethylene Flame. Combust. Flame 113: 333-347

Bhargava, A. \& Westmoreland, P.R. 1998b MBMS Analysis of a Fuel-Lean Ethylene Flame. Combust. Flame 115: 456-467.

Bowman, C.T., Frenklach, M., Gardiner, W.R. \& Smith, G. 1999 “The 'GRI 3.0' Chemical Kinetic Mechanism.” http://www.me.berkeley.edu/gri_mech/.

Davis, S.G., Law, C.K. \& Wang, H. 1999 Propene Pyrolysis and Oxidation Kinetics in Flow Reactor and Laminar Flames. Combust. Flame 119: 375-399.

Edwards, T. 1996 Fuels and Fuel System Area: Air Force Perspective. AFOSR/NASA Workshop on Supersonic Scramjet Combustion, 13-16 May 1996, Newport News, VA.

Egolfopoulos, F.N. 1994 Dynamics and Structure of Unsteady, Strained, Laminar, Premixed Flames. Proc. Combust. Inst. 25: 1365-1373.

Egolfopoulos, F.N. \& Campbell C.S. 1996 Unsteady, Counterflowing, Strained Diffusion Flames: Frequency Response and Scaling. J. Fluid Mech., 318: 1-29.

Egolfopoulos, F.N. \& Dimotakis, P.E. 1998 Non-Premixed Hydrocarbon Ignition at High Strain Rates. Proc. Combust. Inst. 27: 641-648.

Egolfopoulos, F.N. \& Dimotakis, P.E. 2000 Effects of Additives on the Non-Premixed Ignition of Ethylene in Air. Combust. Sci. Tech. 156: 173-199. 
Egolfopoulos, F.N., Zhu, D.L. \& Law, C.K. 1990 Experimental and Numerical Determination of Laminar Flame Speeds: Mixtures of $\mathrm{C}_{2}$-Hydrocarbons with Oxygen and Nitrogen. Proc. Combust. Inst. 23: 471-478.

Frenklach, M., Wang, H., Goldenberg, M., Smith, G.P., Golden, D.M., Bowman, C.T., Hanson, R.K., Gardiner, W.C. \& Lissianski, V. 1995 GRI-Mech-An Optimized Detailed Chemical Reaction Mechanism for Methane Combustion. GRI Technical Report No. GRI$95 / 0058$.

Kee, R. J., Warnatz, J. \& Miller J.A. 1983 A FORTRAN Computer Code Package for the Evaluation of Gas-Phase Viscosities, Conductivities, and Diffusion Coefficients. Sandia Report SAND83-8209.

Kee, R.J., Grcar, J. F., Smooke, M.D. \& Miller J.A. 1985 A FORTRAN Program for Modeling Steady Laminar One-Dimensional Premixed Flames. Sandia Report SAND858240 .

Kee, R. J., Rupley, F. M. \& Miller J.A. 1989 Chemkin-II: A FORTRAN Chemical Kinetics Package for the Analysis of Gas-Phase Chemical Kinetics. Sandia Report SAND89-8009.

Laskin, A. \& Wang, H. 1999 On initiation reactions of acetylene oxidation in shock tubes. Chem. Phys. Lett. 303, 43-49.

Law, C.K. \& Egolfopoulos, F.N. 1992 A Unified Chain-Thermal Theory of Fundamental Flammability Limits. Proc. Combust. Inst. 24: 137-144.

Marinov, N.M. (1998) “A Detailed Chemical Kinetic Model for High Temperature Ethanol Oxidation," Int. J. Chem. Kin., in press.

Marinov, N.M., Pitz, W.J. \& Westbrook, C.K. 1995 Numerical Study of Ethylene and Acetylene Laminar Flame Speeds. Joint Technical Meeting, Central States and Western States Section/CI, April 23-26.

Nishioka, M., Law, C.K. \& Takeno, T. 1996 A Flame-Controlling Continuation Method for Generating S-Curve Responses with Detailed Chemistry. C Combust. Flame 104: 328-342. 
Sun, C.J., Sung, C.J., Wang, H. \& Law, C.K. 1996 On the Structure of Non-Sooting Counterflow Ethylene and Acetylene Diffusion Flames. Combust. Flame 107, 321-335.

Tan, Y., Dagaut, P., Cathonnet, M., Boettner, J.C., Bachman, J.S. \& Carlier, P. 1994 Natural Gas and Blends Oxidation and Ignition: Experiments and Modeling. Proc. Combust. Inst. 25: $1563-1569$.

Wang, H. \& Frenklach, M. 1997 A Detailed Kinetic Modeling Study of Aromatics Formation in Laminar Premixed Acetylene and Ethylene Flames. Combust. and Flame 110:173-221.

Wang, H., Laskin, A., Djurisic, Z. M., Law, C. K., Davis, S. G. \& Zhu, D. L. 1999 A comprehensive mechanism of $\mathrm{C}_{2} \mathrm{H}_{\mathrm{x}}$ and $\mathrm{C}_{3} \mathrm{H}_{\mathrm{x}}$ fuel combustion. Chemical and Physical Processes of Combustion, the 1999 Fall Technical Meeting of the Eastern States Section of the Combustion Institute, Raleigh, NC, pp. 129-132.

Westbrook, C.K. \& Dryer, F.L. 1981 Chemical Kinetics and Modeling of Combustion Processes. Proc. Combust. Inst. 18: 749-767. 